\title{
Chemical Composition and Antioxidant Activity of Date Seeds from Different Tunisian Date Palm Cultivars
}

\author{
Dhaouadi, K. ${ }^{1}$, Ammar, H. ${ }^{1}$, Khouja, M. ${ }^{2,3}$, Sebei, H. ${ }^{1}$ and López, S. ${ }^{4}$ \\ 1. Ecole Supérieure d'Agriculture de Mograne, 1121 Mograne, Zaghouan, Tunisia \\ 2. Institut National des Sciences Appliquées et de Technologie (INSAT), Tunisia \\ 3. Institut National de Recherche en Génie Rural, Eaux et Forêts (INRGREF), Tunisia \\ 4. Instituto de Ganadería de Montaña, CSIC-Universidad de León, Departamento de Producción Animal, Universidad de León, León \\ 24007, Spain
}

\begin{abstract}
Chemical composition, polyphenolic and flavonoid contents, and antioxidant activity were determined in date seeds derived from four Tunisian date palm (Phoenix dactylifera) cultivars namely: Goundi, Chekena, Mnekher and Remtha. Sodium and potassium contents in date seeds were determined by flame photometry, phenolic compounds by the Folin-Ciocalteu method, flavonoids by colorimetric quantification, and the antioxidant activity by the DPPH free radical scavenging method. Crude protein content varied widely $(p<0.001)$ between date seed varieties and ranged from 3.95 (Goundi) to $7.51 \%$ DM (Chekena). No significant differences $(p>0.001)$ were detected between seed varieties for their dry matter (DM) and ash contents. However, sodium, potassium and phosphorus varied widely $(p<0.001)$ between varieties. The highest phenolic content $(p<0.001)$ was observed in Goundi (39.4 mg gallic acid equivalent (GAE)/g DM) and Remtha (36.6 mg GAE/g DM) seed varieties. Likewise, Goundi had the highest $(p<0.001)$ flavonoid content $(16.4 \mathrm{mg}$ quercetin equivalent $(\mathrm{QE}) / \mathrm{g} \mathrm{DM})$ and antioxidant activity $(1,807 \mu \mathrm{M}$ Trolox equivalent antioxidant capacity (TEAC)/g DM); however the lowest values $(p<0.001)$ of phenolic $(19.2 \mathrm{mg}$ GAE/g DM), flavonoid $(8.8 \mathrm{mg} \mathrm{QE} / \mathrm{g} \mathrm{DM})$ and antioxidant activity $(682 \mu \mathrm{M}$ TEAC/g DM) were observed for Chekena seeds. Further studies are needed to verify the potential of date seeds as alternative for animal nutrition.
\end{abstract}

Key words: Date seeds, chemical composition, phenolic, flavonoid, antioxidant activity.

\section{Introduction}

Date palm tree (Phoenix dactylifera L.) is an important plantation crop in many regions of the world. The fruit of this tree (date) is constituted by a fleshy pericarp and a seed (pit). Flesh (the edible part) contains mainly sugars ( $81-88 \%$, mostly fructose, glucose and sucrose), but also some dietary fibre $(\sim 5-8.5 \%)$ and smaller amounts of protein, fat, ash and polyphenols [1]. However, seeds (the byproduct), so called pits, are often used in animal nutrition. Vandepopuliere et al. [2] incorporated date pits in broiler diets up to $27 \%$, attaining performance (weight gain) and feed conversion comparable to a

Corresponding author: Ammar Hajer, $\mathrm{PhD}$, lecturer, research fields: animal production science and animal nutrition. conventional diet. Beneficial effects of either date fruits [3] or date seeds [4] have been tested on animal reproductive performances. Date-pit extracts have a potential to recover the normal functional status in damaged liver, and to protect against hepatotoxicity in rats [5]. These results suggest that these by-products could be regarded as functional foods containing phytochemicals with potential biological activity such as tannins or resistant starch. Studies reported on the chemical composition of date seeds $[6,7,8]$ revealed high fibre $(75-80 \%)$ content, containing also fat $(10-12 \%)$ and proteins (5-6\%). Date pits could be considered a potential source of nutrients with some bioactive molecules [6, 7]. Soong and Borlow [9] have reported that the total phenolic contents of seeds of several fruits were higher than their edible flesh; 
therefore, seeds can be a potential source of phenolics. Tunisia is considered to be one of the most date producing countries, with a mean annual yield of date fruits of $125,000 \mathrm{t}$. There are more than 250 varieties of date palms, mainly dominated by Deglet Nour. Approximately $10 \%$ of the fruit is the pit, representing a substantial amount of biomass that can be recycled as animal feedstuff because of its nutrient contents $[6$, 8]. Despite the large number of varieties of dates grown in Tunisia and the importance of these fruits, to our best knowledge limited data are available on the compositional and antioxidant activity of the seeds derived from these tree byproducts. Thus, the main objective of the present study was to screen and compare the existing differences in chemical composition and antioxidant activity of seeds from four Tunisian palm date varieties.

\section{Material and Methods}

\subsection{Date Seeds}

Four varieties of date palm fruits namely Mnekher, Goundi, Chekena and Remtha were collected from the oasis of Tozeur (South-west Tunisia) at the "Tamr" stage (full ripeness). The geolocations of the date palm trees used in the study, as determined by a Global Positioning System (GPS, Magellan Professional Solutions, Inc), were: Mnekher (latitude $33^{\circ} 58^{\prime} 41^{\prime \prime} \mathrm{N}$; longitude $008^{\circ} 12^{\prime} 33^{\prime \prime} \mathrm{E}$; altitude $49.5 \mathrm{~m}$ ), Goundi (latitude 3354'30 "N; longitude 008 $09^{\circ} 53^{\prime \prime} \mathrm{E}$; altitude $16.5 \mathrm{~m}$ ), Remtha (latitude $33^{\circ} 58^{\prime} 42$ "N; longitude $008^{\circ} 12^{\prime} 36^{\prime \prime} \mathrm{E}$; altitude $55.6 \mathrm{~m}$ ), and Chekena (latitude $33^{\circ} 54^{\prime} 21^{\prime \prime} \mathrm{N}$; longitude $008^{\circ} 09^{\prime} 36^{\prime \prime}$ $\mathrm{E}$; altitude $21.2 \mathrm{~m}$ ). Date seeds of the four cultivars were directly handpicked eliminating those from damaged fruits. The selected seeds were soaked in water, washed to remove any adhering flesh and finally oven-dried at $55{ }^{\circ} \mathrm{C}$ for $48 \mathrm{~h}$. The dried seeds were then ground through a 1-mm screen and preserved in dark bottles for later analysis.

\subsection{Chemical Analysis}

Chemical composition, extraction of phenolic compounds, flavonoid and antioxidant activity analyses were carried out in triplicate. Dry matter (DM), Kjeldahl $\mathrm{N}$ and organic matter contents were determined according to the AOAC [10]. In the case of ash determination, a ground sample $(1 \mathrm{~g})$ of each cultivar was weighed out into sintered porcelain crucibles and mixed with $10 \mathrm{~mL}$ of nitric acid $\left(\mathrm{HNO}_{3}\right)$. The mixture was then subjected to a prior mineralization in a sandbox followed by incineration in the muffle furnace at 150,250 and $350{ }^{\circ} \mathrm{C}$ for one hour each temperature and then at $460{ }^{\circ} \mathrm{C}$ for 6 hours. Mineral contents were determined by carbon removal adding $2 \mathrm{~mL}$ distilled (demineralized) $\mathrm{H}_{2} \mathrm{O}$ to the ashed recovered in the crucibles and then evaporating in a sandbox. Then $7 \mathrm{~mL}$ of $\mathrm{HCl}$ was added followed by evaporation. The residue was dissolved in $7 \mathrm{~mL}$ of $\mathrm{HCl} 5 \%$ filtered through ashless paper and conserved at $4{ }^{\circ} \mathrm{C}$ until further analysis. An aliquot $(3 \mathrm{ml})$ of each filtrate was mixed with $18 \mathrm{~mL}$ of lanthanum chloride, $2.1 \mathrm{~mL}$ of $\mathrm{HCl}$ and $6.9 \mathrm{~mL}$ of distilled water. Potassium and sodium contents were analyzed using a flame ionization spectrophotometer (Flame Photometer 410, SCHERWOOD, Germany). Phosphorus content was determined using the colorimetric method proposed by Didier de Saint-Amand and Cas [11].

\subsection{Extraction of Polyphenolic Compounds and Flavoniods}

Extraction was carried out using the method described by Dhaouadi et al. [12], with some modifications. Seed samples $(1 \mathrm{~g})$ were mixed with 5 $\mathrm{mL}$ of water, sonicated for $30 \mathrm{~min}$ and centrifugated at $10,000 \times g$ for $15 \mathrm{~min}$. Cold acetone $\left(-20^{\circ} \mathrm{C}\right)$ was added to the supernatant (ratio 8:2 v:v) following a centrifugation at $12,000 \times g$ for $10 \mathrm{~min}$. Only the supernatant was collected and concentrated using a rotary evaporator $\left(60^{\circ} \mathrm{C}\right)$. The extracts were then conserved at $-20{ }^{\circ} \mathrm{C}$. Total phenolic (TP) was quantified following the method described by Wolfe 
et al. [13], mixing $50 \mu \mathrm{L}$ of seed extracts (diluted 20 times in water) with $50 \mu \mathrm{L}$ of water and $400 \mu \mathrm{L}$ of $10 \%$ Folin-Ciocalteu reagent (Sigma Aldrich, Germany). The mix was incubated (30 $\mathrm{min})$ at room temperature, and then $500 \mu \mathrm{L}$ of $7.5 \%$ sodium bicarbonate were added to the mixture. Absorbance was measured against a blank at $765 \mathrm{~nm}$ using a UV/Vis Jenway 6300 spectrophotometer. Gallic acid (Sigma Aldrich) was used as a standard and the concentration of TP was expressed in $\mathrm{mg}$ standard equivalent $\mathrm{g}^{-1}$ DM. Total flavonoids content was determined using colorimetric method of Yi et al. [14], mixing $1 \mathrm{~mL}$ of diluted sample with $2 \%$ aluminum chloride (Sigma Aldrich) methanolic solution and incubating for $15 \mathrm{~min}$ at $25{ }^{\circ} \mathrm{C}$. Absorbance was measured against a blank at $430 \mathrm{~nm}$ using quercetin as the standard. Results were expressed in $\mathrm{mg}$ standard equivalent $\mathrm{g}^{-1} \mathrm{DM}$.

\subsection{Antioxidant Activity}

The antiradical activity of the phenolic extracts was evaluated as the scavenging of the free anionic DPPH radical. Sample solution $(50 \mu \mathrm{L})$ or standard trolox solutions at different concentrations was added to 1 $\mathrm{mL}$ of $40 \mu \mathrm{M}$ DPPH in methanol. The mixture was shaken vigorously. After incubation $(1 \mathrm{~h})$, changes in colour (from deep violet to dark yellow) were measured at $517 \mathrm{~nm}$. The Trolox equivalent antioxidant capacity (TEAC) was calculated from the linear equation resulting from regressing known solutions of Trolox $(0.05$ to $0.8 \mu \mathrm{M})$ against absorbance.

\subsection{Statistical Analysis}

Three replicates for each date palm cultivar were used. Statistical differences among varieties in the chemical composition, phenolic and flavonoid compounds and antioxidant activity were evaluated by one-way analysis of variance (ANOVA) followed by Student-Newman-Keuls post hoc test for differences among multiple means (GLM procedure). Values of different parameters were expressed as the mean \pm standard deviation.

\section{Results and Discussion}

In this present study four Tunisian date palm varieties namely Mnekher, Goundi, Remtha and Chekena were screened for their chemical composition, phenolic and flavonoid contents and antioxidant activity.

\subsection{Chemical Composition}

To our best knowledge few works have been reported on date seeds, particularly on their chemical composition $[8,6,15]$. Dry matter and ash contents of the screened varieties varied in narrow ranges, $67.8-73.7 \%$ and $1.79-2.16 \%$, respectively, with no significant differences $(p>0.001)$ between date varieties (Table 1). Previous results revealed high DM contents $(87-97 \%)$ in 23 date pits varieties [6, 7, 16-19]. In the same varieties, ash contents (0.84-1.20\%) were lower than those observed in our study (1.79-2.16\%). Low ash contents were also recorded in seeds of Ruzeiz and Sifri date cultivars (1.1\%) [20]. Ash contents reported herein varied $(p<$ 0.001 ) between varieties in agreement with those found by Herchi et al. [21] and Mohamed et al. [22]. These variations could be attributed to differences in plant cultivar, agronomical (harvest/postharvest practices) or environmental (climate, soil fertility, etc.) factors. Amongst the analyzed minerals, potassium presented the highest proportion $(0.35-0.61 \%)$, followed by phosphorus $(0.22-0.28 \%)$ and sodium (0.05-0.09\%); in agreement with other authors $[6,15$, 20,23 ] who concluded that $\mathrm{K}$ is the most predominant macromineral in pits of different date palm varieties. Significant differences $(p<0.001)$ between varieties were observed for all the minerals. Studies reported by Trabzuni et al. [23] revealed the occurrence of some essential trace elements (Fe, I, Se, Zn) in Saudi Arabian 
Journal of Food Science and Engineering 9 (2019) 123-130

doi: $10.17265 / 2159-5828 / 2019.04 .001$

Table 1 Chemical composition (\% DM, unless otherwise stated) of date seeds of four Tunisian palm date varieties.

\begin{tabular}{lllll}
\hline & \multicolumn{4}{c}{ Variety } \\
\cline { 2 - 4 } & Mnekher & Chekena & Gondi & Remtha \\
\hline Dry matter (\% fresh matter) & $67.8^{\mathrm{a}} \pm 0.95$ & $69.2^{\mathrm{a}} \pm 0.94$ & $73.7^{\mathrm{a}} \pm 1.05$ & $69.9^{\mathrm{a}} \pm 0.72$ \\
Ash & $1.85^{\mathrm{a}} \pm 0.098$ & $1.79^{\mathrm{a}} \pm 0.098$ & $2.16^{\mathrm{a}} \pm 0.098$ & $1.90^{\mathrm{a}} \pm 0.092$ \\
Crude protein & $5.23^{\mathrm{b}} \pm 0.167$ & $7.51^{\mathrm{a}} \pm 0.162$ & $3.95^{\mathrm{c}} \pm 0.052$ & $7.01^{\mathrm{a}} \pm 0.398$ \\
Potassium & $0.50^{\mathrm{b}} \pm 0.012$ & $0.58^{\mathrm{a}} \pm 0.012$ & $0.35^{\mathrm{c}} \pm 0.006$ & $0.61^{\mathrm{a}} \pm 0.006$ \\
Phosphorus & $0.27^{\mathrm{a}} \pm 0.0029$ & $0.22^{\mathrm{c}} \pm 0.0052$ & $0.25^{\mathrm{b}} \pm 0.0012$ & $0.28^{\mathrm{a}} \pm 0.0012$ \\
Sodium & $0.06^{\mathrm{c}} \pm 0.002$ & $0.09^{\mathrm{a}} \pm 0.002$ & $0.05^{\mathrm{d}} \pm 0.003$ & $0.07^{\mathrm{b}} \pm 0.002$ \\
\hline
\end{tabular}

Within the same row, values with different letters $(a, b, c)$ are significantly different $(p<0.001)$.

date pits. Heavy metals $(\mathrm{Pb}, \mathrm{Cd}, \mathrm{Al}, \mathrm{Sb})$ and rare metals ( $\mathrm{Rb}, \mathrm{Cs}, \mathrm{La}, \mathrm{In})$ can be also detected in date pits. The characteristic mineral composition of date seeds may be due to the capacity of bioaccumulation by the plant, absorbing considerable amounts of mineral elements from the soil, which are stored in tissues and fruits [24].

The crud protein content (CP) in date seeds varied widely among the four cultivars (4-7.5\%) corresponding the lowest value to Goundi seeds and the highest to Remtha. Similar results were reported earlier by Habib and Ibrahim [18] and Hossain et al. [25], although lower CP contents were reported in date seeds from Saudi cultivars $(1.8-2.6 \%)$ by Trabzuni et al. [23]. Such variations could be attributed to differences in date palm variety, ripening stage, agronomical management, soil fertility, climatic conditions and other environmental factors. Although, regardless of the cultivar, protein content in dates is relatively low $(<10 \%)$ and probably of limited digestibility. Fayadh and Al-Showiman [26] suggested that the biological value of this protein could be of value to animals considering its composition in essential amino acids. Date seeds are rich in carbohydrates, exceeding $51 \%$ in most date palm cultivars [21, 23, 25]. Date seeds can represent a source of fiber and carbohydrates in animal feeding, with levels of inclusion in ruminant diets of up to $50-75 \%$ [27].

\subsection{Phenolics and Flavonoids}

Plants secondary metabolites (e.g., polyphenols, flavonoids) may have valuable bioactive properties for farm animals [28]. Although different standards have been used for quantification of phenolics, date seeds are consistently characterised by a high content in phenolic compounds [17, 19, 20, 29]. Seeds contain more phenolics than other date by-products [17]. Our results (Table 2) were generally in agreement with those recorded for other three date tree varieties (Mabseeli, Um-sellah and Shahal) reported by Al-Farsi et al. [17], and in line with values determined for other date seeds and varieties, collected from different countries and under different conditions [1, 23, 30-32].

The differences among studies may be related to the cultivars, fruit moisture, maturity, environmental factors, and to extraction conditions for analytical determination $[1,32]$.

Solubility of polyphenols is affected by the type of solvents used and its polarity [33], and different types of polyphenols present in the date-seeds could exhibit different polarities. Aqueous acetone dissolves hydrophilic and high molecular weight compounds as compared with an only aqueous solvent [34]. Al-Farsi et al. [17] confirmed that flavonoids and phenolics have similar extraction patterns, lowest with $100 \%$ acetone and the highest with $50 \%$ aqueous acetone. Conversely, more phenolics can be extracted from blackcurrant leaves and buds using 50\% aqueous acetone than with methanol, acetate or glycine buffer [35]. In our study $80 \%$ acetone was used as solvent, based on the conclusions drawn by Zhao et al. [36] who observed greater phenolic extraction with $80 \%$ 
acetone compared with other solvents $(80 \%$ ethanol, $80 \%$ methanol or water). Acetone is also classified as a low-toxicity solvent, in comparison with methanol [37]. The amount of polyphenols extracted from date seeds is also increased as extraction temperature is increased [19], because temperature augments both the solubility of solute and the diffusion coefficient [29]. Heating may also weaken the date seed tissue matrices and loose some of the bonds of phenols with proteins or polysaccharides [38]. In our study, the temperature for extraction of phenolic/polyphenol compounds was $60^{\circ} \mathrm{C}$. The boiling point of acetone is $56.2{ }^{\circ} \mathrm{C}$ [17], and as acetone is lost by volatilization the acetone to water ratio is decreased in the aqueous solution, affecting the solvent to solute ratio and increasing the oxidation of phenolics. There is also some discrepancy in relation to the extraction time. In our determinations, extraction was for $10 \mathrm{~min}$, but other authors have suggested extending the extraction time up to one [17] or even three hours [39] depending on the vegetable matrix from which phenolics are to be extracted.

The flavonoid content in date seeds varied significantly $(p<0.001)$ among cultivars, and varieties were ranked in the same order to that observed with phenolics: Gondi $>$ Remtha $>$ Chekena $>$ Mnekher. Al-Farsi and Lee [29] have reported similar flavonoid contents in Oman date seeds after extraction with pure acetone and using catechin as standard. The values were consistently increased when a $50 \%$ acetone aqueous solution was used as the solvent for flavonoid extraction [29]. Other authors have reported lower concentrations of flavonoids in Iranian dry date fruits [31] or in date seeds from three Saudi Arabian cultivars [23]. Again, factors such as variety, geographic origin, growing conditions, fertilizer, soil type, season, maturity, sunlight during ripening or storage conditions could explain part of the observed variability among studies. As compared with date fruits, seeds usually contain more flavoniods [17, 22]. Plant flavonoids have been considered functional secondary metabolites with possible benefits, such antioxidant and radical scavenging activities or protection for some chronic, cardiovascular or oncogenic diseases [40]. Based on their composition, date seeds have a potential to be used to obtain extracts rich in phenolics and flavonoids to be used as functional compounds for humans and animals.

\subsection{Antioxidant Activity}

Phenolic and flavonoid compounds may have a natural antioxidant activity [41, 42]. Different techniques have been used to quantify the antioxidant capacity of plant products, and the extensively recognized DPPH procedure was used in our study. Among the four varieties studied, date seeds of Gondi had the highest $(p<0.001)$ antioxidant activity, followed by Remtha, Chekena and Mnekher (Table 2). The antioxidant activity of these by-products can be attributed to the presence of flavonoids, phenolics and other antioxidant compounds (ascorbic acid, vitamin E and carotenoids) [16]. Al-Farsi et al. [17] and Wu et al. [43] measured total antioxidant activity in two date varieties using a different method (lipophilic and hydrophilic ORACFL) and their values were lower

Table 2 Total phenolic and flavonoid contents and antioxidant activity of date seeds of four Tunisian palm date varieties.

\begin{tabular}{lllc}
\hline & \multicolumn{2}{c}{ Variety } \\
\cline { 2 - 4 } & Mnekher & Chekena & Gondi \\
\hline $\begin{array}{l}\text { Total phenolics (mg gallic acid equivalents/g dry } \\
\text { matter) }\end{array}$ & $19.2^{\mathrm{c}} \pm 0.68$ & $24.3^{\mathrm{b}} \pm 0.87$ & $39.4^{\mathrm{a}} \pm 0.73$ \\
$\begin{array}{l}\text { Flavonoids (mg quercetin equivalents/g dry matter) } \\
\begin{array}{l}\text { Antioxidant activity ( } \mu \text { mol Trolox equivalent } \\
\text { antioxidant capacity/g dry matter) }\end{array}\end{array}$ & $688^{\mathrm{c}} \pm 0.11$ & $10.4^{\mathrm{b}} \pm 0.13$ & $16.3^{\mathrm{a}} \pm 0.06$ \\
\hline
\end{tabular}

Within the same row, values with different letters $(a, b, c)$ are significantly different $(p<0.05)$. 
than those observed in our study. The method used herein (DPPH) is highly sensitive to active ingredients present in low concentrations and can handle a large number of samples in a very short time. This procedure is commonly followed when measuring free radical scavenging activity of different plant extracts [44]. As there is no standard method for antioxidant analysis, such differences among studies are expected. It is suggested to use two or more assays to measure antioxidant properties in heterogeneous samples. Other factors such as date varieties and concentration of phenolic compounds, could be responsible for these differences. Mansouri et al. [30] confirmed that DPPH radical scavenging activity of date fruit was highly correlated with the phenolics content. Antioxidant activity in dates and pits would be greater than in other fleshy fruits such as figs, prunes or raisins [17, 43]. Thus, the high antioxidant activity of date seeds could support their use as natural antioxidants with medicinal nutraceutical or pharmaceutical purposes [29].

\section{Conclusions}

The results of the present study may highlight the potential importance of date seeds as a good source of minerals, total phenolics and flavonoids that could potentially be considered as an inexpensive source of natural antioxidants. Given their low protein content $(<10 \%)$, date seeds can be used as an alternative substitution feed only in harsh conditions with scarcity of more conventional feeds. However, their contents in secondary compounds with biological activity open the question on whether they can have a promising potential as functional feedstuffs. There are significant differences among date palm tree varieties in the composition, concentration of secondary compounds and antioxidant acitivy of date pits. Based on the concentrations in phenolic and flavonoid componds and antioxidant activity in date seeds, varieties are ranked in the order: Gondi $>$ Remtha $>$ Chekena $>$ Mnekher. Further research is warranted to identify and quantify the chemical components and fractions, and secondary metabolites in date seeds, and to explore other properties of these date by-products that could be of relevance for animal nutrition.

\section{Contribution}

Ammar Hajer contributed equally in the elaboration of the manuscript as well as the principal author.

\section{References}

[1] Al-Farsi, M., Alasalvar, C., Morris, A., Baron, M., and Shahidi, F. 2005. "Comparison of Antioxidant Activity, Anthocyanins, Carotenoids, and Phenolics of Three Native Fresh and Sun-Dried Date (Phoenix dactylifera L.) Varieties Grown in Oman." J Agric Food Chem 53: 7592-9.

[2] Vandepopuliere, J. M., Al-Yousef, Y., and Lyons, J. J. 1995. "Dates and Date Pits as Ingredients in Broiler Starting and Coturnix Quail Breeder Diets.” Poult. Sci. 74: 1134-42.

[3] El Arem, A., Lahouar, L., Saafi, E. B., Thouri, A., Ghrairi, F., Houas, Z., Neffati, F., and Achour, L. 2017. "Dichloroacetic Acid-Induced Testicular Toxicity in Male Rats and the Protective Effect of Date Fruit Extract." BMC Pharmacol Toxicol 18: 17. https://doi.org/10.1186/s40360-017-0127-8.

[4] Lim, T. K. 2012. "Phoenix Dactylifera." In Edible Medicinal and Non-medicinal Plants, Volume 1 Fruits, 1st ed., edited by T. K. Lim. Dordrecht, Netherlands: Springer, 407-18.

[5] Al-Qarawi, A. A., Mousa, H. M., Ali, B. H., Abdel-Rahman, H., and El-Mougy, S. A. 2004. "Protective Effect of Extracts from Dates (Phoenix dactylifera L.) on Carbon Tetrachloride-Induced Hepatotoxicity in Rats.” Inter. J. Appl. Res. Vet. Med. 2: 176-80.

[6] Hamada, J. S., Hashim, I. B., and Sharif, F. A. 2002. "Preliminary Analysis and Potential Uses of Date Pits in Foods." Food Chem. 76: 135-7.

[7] Besbes, S., Blecker, C., Deroanne, C., Drira, N. E., and Attia, H. 2004. "Date Seeds: Chemical Composition and Characteristic Profiles of the Lipid Fraction." Food Chem. 84: 577-84.

[8] Al-Hooti, S., Sidhu, J. S., and Qabazard, H. 1998. "Chemical Composition of Seeds Date Fruit Cultivars of United Arab Emirates.” J. Food Sci. Tech. 35: 44-6.

[9] Soong, Y. Y., and Barlow, P. J. 2004 "Antioxidant Activity and Phenolic Content of Selected Fruit Seeds." Food Chem. 88: 411-7. 
[10] AOAC. 2000. Official Methods of Analysis. Association of Official Analytical Chemists 17th Edition. Washington.

[11] Didier de Saint-Amand, J. D., and Cas, G. 1967. Dosage des éléments minéraux majeurs chez les végétaux. Méthodes appliquées au laboratoire de diagnostic foliaire de l'ORSTOM. Office de la recherche scientifique et technique outre-mer (ORSTOM), Institut de recherche pour le développement (IRD), Paris.

[12] Dhaouadi, K., Raboudi, F., Estevan, C., Barrajon, E., Vilanova, E., Hamdaoui, M., and Fattouch, S. 2011. "Cell Viability Effects and Antioxidant and Antimicrobial Activities of Tunisian Date Syrup (Rub El Tamer) Polyphenolic Extracts.” J. Agric. Food Chem. 59: 402-6.

[13] Wolfe, K., Wu, X., and Liu, R. H. 2003. "Antioxidant Activity of Apple Peels." J. Agric. Food Chem. 51: 609-14.

[14] Yi, Z. B., Yu, Y., Liang, Y. Z., and Zeng, B. 2008. "In Vitro Antioxidant and Antimicrobial Activities of the Extract of Pericarpium Citri Reticulatae of a New Citrus Cultivar and Its Main Flavonoids." LWT-Food Sci Technol 41: 597-603.

[15] Nehdi, I., Omri, S., Khalil, M. I., and Al-Resayes, S. I. 2010. "Characteristics and Chemical Composition of Date Palm (Phoenix canariensis) Seeds and Seed Oil." Ind. Crop. Prod. 32: 360-5.

[16] Chaira, N., Ferchichi, A., Mrabet, A., and Sghairoun, M. 2007. "Chemical Composition of the Flesh and the Pit of Date Palm Fruit and Radical Scavenging Activity of Their Extracts.” Pak. J. Biol. Sci. 10: 2202-7.

[17] Al-Farsi, M., Alasalvar, C., Al-Abid, M., Al-Shoaily, K., Al-Amry, M., and Al-Rawahy, F. 2007. "Compositional and Functional Characteristics of Dates, Syrups, and Their By-Products." Food Chem. 104: 943-7.

[18] Habib, H. M., Kamal, H., Ibrahim, W. H., and Al Dhaheri, A. S. 2013. "Carotenoids, Fat Soluble Vitamins and Fatty Acid Profiles of 18 Varieties of Date Seed Oil." Ind. Crop. Prod. 42: 567-72.

[19] Suresh, S., Guizani, N., Al-Ruzeiki, M., Al-Hadhrami, A., Al-Dohani, H., Al-Kindi, I., and Rahman, M. S. 2013. "Thermal Characteristics, Chemical Composition and Polyphenol Contents of Date-Pits Powder.” J. Food Eng. 119: 668-79.

[20] Sawaya, W. N., Khalil, J. K., and, Safi, W. J. 1984. "Chemical Composition and Nutritional Quality of Date Seeds.” J. Food Sci. 49: 617-9.

[21] Herchi, W., Kallel, H., and Boukhchina, S. 2014. "Physicochemical Properties and Antioxidant Activity of Tunisian Date Palm (Phoenix dactylifera L.) Oil as Affected by Different Extraction Methods." Food Sci. Technol. Campinas. 34: 464-70.

[22] Mohamed, R. M. A., Fageer, A. S. M., Eltayeb, M. M., and Ahmed, I. A. M. 2014. "Chemical Composition,
Antioxidant Capacity, and Mineral Extractability of Sudanese Date Palm (Phoenix dactylifera L.) Fruits." Food Sci. Nutr. 2: 478-89.

[23] Trabzuni, D. M., Ahmed, S. E. B., and Abu-Tarboush, H. M. 2014. "Chemical Composition, Minerals and Antioxidants of the Heart of Date Palm from Three Saudi Cultivars." Food Nutr. Sci. 5: 1374-82. http://dx.doi.org/10.4236/fns.2014. 514150.

[24] Fontes Vieira, P. A., Gontijo, D. C., Vieira, B. C., Fontes, E. A. F., Assunção, L. S., Leite, J. P. V., Oliveira, M. G. A., and Kasuya, M. C. M. 2013. "Antioxidant Activities, Total Phenolics and Metal Content in Pleurotus ostreatus Mushrooms Enriched with Iron, Zinc or Lithium." LWT-Food Sci. Technol. 54: 421-5. http://dx.doi.org/10.1016/j.lwt.2013.06.016.

[25] Hossain, M. Z., Waly, M. I., Singh, V., Sequeira, V., and Rahman, M. S. 2014. "Chemical Composition of Date-Pits and Its Potential for Developing Value-Added Product-A Review." Pol. J. Food Nutr. Sci. 64: 215-26.

[26] Fayadh, J. M., and Al-Showiman, S. S. 1990. "A Review on Chemical Composition of Date Palm (Phoenix dactylifera L.).” J. Chem. Soc. Pak. 12: 84-103.

[27] Alwash, A. H., and De Peters, E. J. 1982. "The Use of Date Stones for Feeding and Fattening Ruminant Animals." World Rev. Anim. Prod. 18: 29-32.

[28] Lançon, A., Michaille, J. J., and Latruffe, N. 2013. "Effects of Dietary Phytophenols on the Expression of microRNAs Involved in Mammalian Cell Homeostasis." J. Sci. Food Agric. 93: 3155-64.

[29] Al-Farsi, M. A., and Lee, C. Y. 2008. "Nutritional and Functional Properties of Dates: A Review". Crit. Rev. Food Sci. Nutr. 48: 877-87.

[30] Mansouri, A., Embarek, G., Kokkalou, E., and Kefalas, P. 2005. "Phenolic Profile and Antioxidant Activity of the Algerian Ripe Date Palm Fruit (Phoenix dactylifera)." Food Chem. 89: 411-20. http://dx.doi.org/10.1016/j.foodchem.2004.02.051

[31] Biglari, F., Al-Karkhi, A. F. M., and Easa, A. M. 2008. "Antioxidant Activity and Phenolic Content of Various Date Palm (Phoenix dactylifera) Fruits from Iran." Food Chem. 107: 1636-41. http://dx.doi.org/10.1016/j.foodchem.2007.10.033.

[32] Benmeddour, Z., Mehinagic, E., Le Meurlay, D., and Louaileche, H. 2013 "Phenolic Composition and Antioxidant Capacities of Ten Algerian Date (Phoenix dactylifera L.) Cultivars: A Comparative Study.” J. Funct Foods 5: 346-54. http://dx.doi.org/10.1016/j.jff.2012.11.005.

[33] Al-Rawahi, A. S., Rahman, M. S., Guizani, N., and Essa, M. M. 2013. "Chemical Composition, Water Sorption Isotherm, and Phenolic Contents in Fresh and Dried Pomegranate Peels." Drying Technol. 31: 257-63.

[34] Dai, J., and Mumper, R. J. 2010. "Plant Phenolics: 
Extraction, Analysis and Their Antioxidant and Anticancer Properties." Molecules 15: 7313-52.

[35] Tabart, J., Kevers, C., Sipel, A., Pincemail, J., Defraigne, J. O., and Dommes, J. 2007. "Optimisation of Extraction of Phenolics and Antioxidants from Black Currant Leaves and Buds and of Stability during Storage." Food Chem. 105: 1268-75.

[36] Zhao, H., Dong, J., Lu, J., Chen, J., Li, Y., Shan, L., Lin, Y., Fan, W., and Gu, G. 2006. "Effects of Extraction Solvent Mixtures on Antioxidant Activity Evaluation and Their Extraction Capacity and Selectivity for Free Phenolic Compounds in Barley (Hordeum vulgare L.)." J. Agric. Food Chem. 54: 7277-86.

[37] Wypych, G. 2001. Handbook of Solvents, 1st ed. Ontario, Canada: ChemTec Publishing.

[38] Shi, J., Yu, J., Pohorly, J., Young, J. C., Bryan, M., and Wu, Y. 2003. "Optimization of the Extraction of Polyphenols from Grape Seed Meal by Aqueous Ethanol Solution." Food Agric. Environ. 1: $42-7$.

[39] Durling, N. E., Catchpole, O. J., Grey, J. B., Webby, R. F., Mitchell, K. I., Foo, L. Y., and Perry, N. B. 2007. "Extraction of Phenolics and Essential Oil from Dried Sage (Salvia officinalis) Using Ethanol-Water Mixtures."
Food Chem 101: 1417-27.

[40] Tapas, A. R., Sakarkar, D. M., and Kakde, R. B. 2008. "Flavonoids as Nutraceuticals: A Review." Trop. J. Pharmacol. Res. 7: 1089-99.

[41] Heim, K. E., Tagliaferro, A. R., and Bobilya, D. J. 2002. "Flavonoid Antioxidants: Chemistry, Metabolism and Structure-Activity Relationships." J. Nutr. Biochem. 13: 572-84. http://dx.doi.org/10.1016/S0955-2863.

[42] Hagerman, A. E., Riedl, K. M., Jones, G. A., Sovik, K. N., Ritchard, N. T., Hartzfeld, P. W., and Riechel, T. L. 1998. "High Molecular Weight Plant Phenolics (Tannins) as Biological Antioxidants.” J. Agric. Food Chem. 46: 1887-92. http://dx.doi.org/10.1021/jf970975b.

[43] Wu, X., Beecher, G. R., Holden, J. M., Haytowitz, D. B., Gebhardt, S. E., and Prior, R. L. 2004. "Lipophilic and Hydrophilic Antioxidant Capacities of Common Foods in the United States.” J. Agric. Food Chem. 52: 4026-37.

[44] Sultana, B., Anwar, F., and Przybylski, R. 2007. "Antioxidant Activity of Phenolic Components Present in Barks of Azadirachta indica, Terminalia arjuna, Acacia nilotica, and Eugenia jambolana Lam. Trees." Food Chem. 104: 1106-14. http://dx.doi.org/10.1016/j.foodchem.2007.01.019. 